\title{
KAJIAN BUDIDAYA IKAN NILEM (Osteochilus hasselti) DALAM UPAYA KONSERVASI SUMBERDAYA IKAN (Studi di Kabupaten Tasikmalaya Provinsi Jawa Barat)
}

\author{
Oleh: \\ Iis Jubaedah dan Aan Hermawan \\ Dosen Jurusan Penyuluhan Perikanan Sekolah Tinggi Perikanan
}

\begin{abstract}
Abstrak
Kajian tentang budidaya ikan nilem telah dilakukan pada bulan Juni sampai dengan Agustus 2009. Penelitian ini bertujuan untuk mengetahui present status dan teknologi pembenihan ikan nilem (Osteochilus hasselti) di Kabupaten Tasikmalaya Provinsi Jawa Barat. Penelitian dilakukan dengan melakukan pengamatan (observasi) dan wawancara pada aspek budidaya ikan nilem di BPBI Singaparna dan pembudidaya ikan. Data dianalisis secara deskriptif kualitatif. Berdasarkan hasil pengamatan dan observasi lapangan, Kabupaten Tasikmalaya memiliki potensi yang cukup besar dalam pengembangan budidaya ikan nilem. Luas areal budidaya ikan nilem 111,61 $\mathrm{Ha}$ atau $37,22 \%$; Persentase nilai produksi ikan nilem pada tahun 2008 sebesar $42,13 \%$ dari total produksi pembenihan ikan air tawar atau sejumlah 679.119.578 ekor; dan sebesar $37,62 \%$ dari total produksi pembesaran ikan air tawar atau sejumlah 6.910 ton. Teknologi budidaya khususnya pembenihan ikan nilem sudah berkembang baik dan diaplikasikan oleh pembudidaya. Pembenihan dilakukan secara semi intensif, pada kolam semi permanen dengan menerapkan seleksi induk sedangkan dalam kegiatan pendederan dilakukan secara polikultur pada kolam tanah. Kegiatan konservasi yang dilakukan adalah konservasi $e x$-situ, yang mencakup pemeliharaan populasi dalam bentuk wadah berupa kolam dan bak, dan konservasi in-situ dengan melakukan restocking di perairan umum. Intensifnya kegiatan budidaya ikan nilem, baik yang dilakukan oleh Balai Benih maupun pembudidaya turut mendukung kemantapan populasi ikan nilem.
\end{abstract}

Kata kunci : Konservasi, budidaya, nilem (Osteochilus hasselti), Kab. Tasikmalaya.

\section{PENDAHULUAN}

\section{Latar Belakang}

Ikan nilem merupakan salah satu komoditas ikan air tawar yang sangat potensial untuk dikembangkan menjadi produk unggulan budidaya perikanan. Di habitat aslinya, ikan ini banyak ditemukan hidup liar di perairan umum terutama di sungai-sungai yang berarus sedang dan berair jernih. Selain itu juga bisa ditemui hidup di rawa-rawa. Dalam kegiatan pembudidayaan, ikan ini banyak dipelihara terutama oleh pembudidaya di Sumatera (khususnya Sumatera Barat) dan di daerah Priangan (Jawa Barat).

Prospek pasar ikan nilem cukup luas, bukan hanya di pasaran lokal, namun juga sudah bisa menembus pasar internasional. Ikan ini terkenal memiliki 
rasa daging dan telur sangat gurih. Permintaan benih ikan nilem ukuran 5 gram cukup tinggi karena diperuntukan sebagai substitusi ikan mas untuk makanan kering "baby fish". Menurut informasi dari pembudidaya ikan nilem di Tasikmalaya, benih ikan nilem umur 1 hari dapat dijual per cawan (umumnya berisi 30.000 ekor) dengan harga mencapai Rp 12.000,00.

Budidaya ikan nilem, dari sisi kesehatan, ekonomi dan kelestarian lingkungan juga dinilai menguntungkan. Karena kebiasannya memakan ganggang, ikan nilem tergolong ikan organik. Keuntungan lainnya dari aspek kelestarian lingkungan, ikan nilem bisa berperan sebagai pembersih kotoran karena kebiasaan makannya. Menurut Husen, 2004, seekor ikan nilem seberat 5 gram bisa menghabiskan pakan berupa ganggang sebanyak $6,4 \mathrm{~kg}$ dalam jaring apung seluas $19 \mathrm{~m}^{2}$ untuk mendapatkan berat 100 gram.

Keberadaan populasi ikan nilem di perairan umum semakin menurun. Penurunan populasi ikan ini selain karena adanya eksploitasi juga diduga akibat perubahan lingkungan perairan. Salah satu langkah yang dapat dilakukan untuk meningkatkan produksi dan menjamin kelestarian ikan nilem adalah melalui pengembangan kegiatan budidaya komoditas ini di masyarakat. Melalui kegiatan ini, produksi dan penyediaan benih ikan dapat ditingkatkan, baik sebagai komoditas komersial maupun untuk peningkatan populasi ikan di perairan umum dengan kegiatan restocking. Oleh karena itu, diperlukan penelitian/kajian tentang teknik budidaya ikan nilem khususnya segmen pembenihan yang diterapkan oleh masyarakat/pembudidaya. Sebagai lokasi kajian dipilih salah satu kabupaten di wilayah priangan yaitu Kabupaten Tasikmalaya, dengan pertimbangan kabupaten ini merupakan salah satu daerah yang populer dengan ikan nilem dan jumlah pembudidaya ikan nilem di daerah tersebut cukup banyak.

\section{Tujuan dan Manfaat}

Penelitian ini bertujuan untuk mengetahui present status dan teknologi pembenihan Ikan Nilem (Osteochilus hasselti) di Kabupaten Tasikmalaya Provinsi Jawa Barat. Hasil penelitian diharapkan dapat dijadikan sebagai referensi teknologi budidaya ikan nilem yang diaplikasikan oleh pembudidaya sekaligus adanya suatu konsep pengembangan konservasi ikan untuk mempertahankan keanekaragaman hayati dan populasinya di perairan dan habitat alaminya.

\section{METODE PENELITIAN}

\section{Lokasi dan Waktu}

Penelitian ini dilaksanakan di Kabupaten Tasikmalaya Provinsi Jawa Barat. Waktu penelitian selama 3 bulan pada bulan Juni sampai Agustus 2009.

\section{Bahan dan Alat}

Bahan penelitian meliputi contoh ikan nilem (Osteochilus hasselti), dan air yang diperoleh dari hasil sampling di lapangan selama penelitian. Alat bantu yang digunakan dalam penelitian ini adalah alat pengambilan contoh air dan bahan analisis kualitas air serta lembar monitoring/pengamatan. 
Metode Pengumpulan Data

Pengumpulan data dilakukan dengan melakukan observasi dan wawancara dengan Balai Pengembangan Benih Ikan (BPBI) Singaparna dan pembudidaya ikan di 3 lokasi yaitu Kecamatan Padakembang, Sukaratu dan Sukarame. Pengamatan parameter kualitas air meliputi fisika dan kimia yaitu suhu, kecerahan, pH, DO (disolved oxygen).

\section{Analisis Data}

Analisis data dilakukan dengan menggunakan analisis deskriptif kualitatif yang disajikan dalam bentuk tabel dan grafik.

\section{HASIL DAN PEMBAHASAN}

\section{Kondisi Umum Wilayah}

Wilayah Kabupaten Tasikmalaya secara geografis berada di sebelah tenggara wilayah Propinsi Jawa Barat, dengan batas-batas wilayah sebagai berikut : Sebelah Utara Kabupaten Majalengka, Ciamis, dan Kota Tasikmalaya; sebelah Barat Kabupaten Garut; sebelah Timur Kabupaten Ciamis dan sebelah Selatan Samudra Indonesia. Secara geografis terletak antara $107^{\circ} 56^{\prime}$ BT - $108^{\circ} 8^{\prime} \mathrm{BT}$ dan $7^{\circ} 10^{\prime} \mathrm{LS}-7^{\circ} 49^{\prime} \mathrm{LS}$ dengan jarak membentang Utara Selatan terjauh $75 \mathrm{Km}$ dan arah Barat Timur 56,25 Km. Luas keseluruhan sebesar 2.563,35 $\mathrm{Km}^{2}$. Sebagian besar wilayahnya berada pada ketinggian antara $0-1.500 \mathrm{~m}$ di atas permukaan laut yang membentang dari arah utara dan yang terendah ke arah selatan. Sebagian kecil wilayahnya yaitu $0,81 \%$ berada pada ketinggian diatas $1.500 \mathrm{~m}$, keadaan iklim umumnya bersifat tropis dan beriklim sedang dengan rata- rata suhu di dataran rendah antara $20^{\circ}-34^{\circ}$

$\mathrm{C}$ dan di dataran tinggi berkisar $18^{\circ}-22^{\circ}$

C. Curah hujan rata-rata 2,072 $\mathrm{mm} /$ tahun, jumlah hari hujan rata-rata 82 hari.

\section{Kondisi Sumber Daya Perikanan}

Kabupaten Tasikmalaya merupakan salah satu daerah yang memiliki potensi kegiatan bisnis perikanan potensial di Jawa Barat terutama perikanan budidaya. Potensi budidaya perikanan ini tersebar di 39 kecamatan dan 348 desa yang ada. Berdasarkan data Dinas Peternakan, Perikanan dan Kelautan Kabupaten Tasikmalaya, potensi budidaya perikanan cabang usaha pembenihan ikan air tawar pada tahun 2008 seluas 366,59 Ha dengan pemanfaatan sejumlah 299,86 $\mathrm{Ha}$ atau sekitar $81,80 \%$. Lahan perikanan ini sebagian besar dimanfaatkan untuk pembenihan ikan air tawar dengan komoditi Ikan Mas, Nila, Nilem, Tawes, Gurame, Lele dan jenis ikan lainnya. Analisis sumberdaya perikanan juga dilakukan pada potensi perairan umum yang dapat dikembangkan untuk kegiatan budidaya perikanan. Data dinas menunjukkan, kabupaten ini memiliki 14 buah danau/situ/waduk/rawa seluas 171,25 Ha yang tersebar di 10 kecamatan dan 20 sungai sepanjang $1.155,50 \mathrm{~km}$.

\section{PRESENT STATUS IKAN NILEM DI KABUPATEN TASIKMALAYA}

\section{Keragaman Komoditas/Strain Ikan Nilem}

Menurut Hardjamulia (1979), warna sisiknya ikan nilem dapat dibedakan menjadi dua, yaitu ikan nilem yang berwarna cokelat kehitaman atau 
cokelat hijau pada punggungnya dan terang di bagian perut dan ikan nilem merah dengan punggung merah atau kemerah-merahan dengan bagian perut agak terang (Hardjamulia, 1979). Berdasarkan hasil pengamatan, strain Ikan Nilem yang berkembang dan dibudidayakan oleh pembudidaya ada 3 strain yaitu Ikan Nilem Merah, Ikan Nilem Were dan Ikan Nilem Cokelat Kehijauan. Ciri morfologi dari ketiga strain tersebut adalah sebagai berikut :

a) Ikan Nilem Merah ; sisik dan sirip berwarna kemerahan dengan bagian perut berwarna putih terang, tubuh memanjang. b) Ikan Nilem Were ; sisik berwarna putih keabuan, bentuk tubuh seperti bandeng.

c) Ikan Nilem Cokelat Kehijuan ; sisik berwarna cokelat kehijauan pada punggung dan badannya, terang di bagian perut, bentuk tubuh memanjang dengan bagian punggung agak tinggi.

Dari ketiga strain nilem di atas yang paling dominan dibudidayakan oleh pembudidaya dan balai benih adalah Ikan Nilem Berwarna Cokelat Kehijauan. Hal ini dikarenakan beberapa kelebihan yang dimilikinya, yakni pertumbuhan lebih cepat dan fekunditas lebih tinggi di bandingkan dengan strain yang lain.

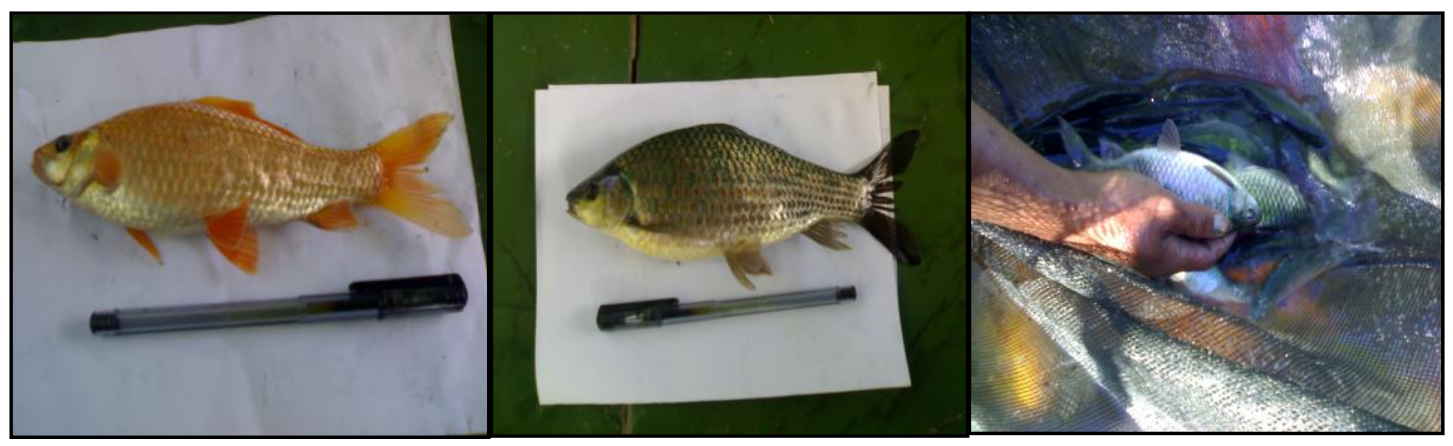

(a)

(b)

(c)

Gambar 1. Tiga strain Ikan Nilem yang dibudidayakan ; a) Ikan Nilem Merah ; b) Ikan Nilem Cokelat Kehijauan ; dan c) Ikan Nilem Were (Dok. Pribadi, Juli 2009)

\section{Kondisi Produksi/Populasi}

Populasi ikan nilem di Kabupaten Tasikmalaya tergolong cukup tinggi, bahkan dibandingkan dengan komoditas ikan air tawar lainnya. Produksi ikan nilem pada tahun 2008 masih mendominasi pada sektor usaha pembenihan dan pembesaran ikan air tawar di Kabupaten Tasikmalaya.
Berdasarkan data Dinas Peternakan Perikanan dan Kelautan Kabupaten Tasikmalaya, persentase nilai produksi ikan nilem pada tahun 2008 sebesar 42,13 $\%$ dari total produksi pembenihan ikan air tawar atau sejumlah 679.119 .578 ekor, sedangkan pada pembesaran sebesar $37,62 \%$ atau sejumlah 6.910 ton. Data produksi pembenihan ikan air tawar dapat dilihat pada Tabel 1. 
Tabel 1. Produksi pembenihan air tawar di Kabupaten Tasikmalaya Tahun 2008.

\begin{tabular}{cccc}
\hline No. & Komoditi & $\begin{array}{c}\text { Produksi } \\
\text { (ekor) }\end{array}$ & $\begin{array}{c}\text { Persentase } \\
(\%)\end{array}$ \\
\hline 1 & Mas & $418,665,008$ & 25.97 \\
2 & Nila & $241,453,126$ & 14.98 \\
$\mathbf{3}$ & Nilem & $\mathbf{6 7 9 , \mathbf { 1 1 9 } , 5 7 8}$ & $\mathbf{4 2 . 1 3}$ \\
4 & Tawes & $118,584,979$ & 7.36 \\
5 & Gurame & $60,381,054$ & 3.75 \\
6 & Lele & $5,030,217$ & 0.31 \\
7 & Lain-lain & $88,872,038$ & 5.51 \\
\hline & Jumlah & $\mathbf{1 , 6 1 2 , 1 0 6 , 0 0 0}$ & $\mathbf{1 0 0 . 0 0}$ \\
\hline
\end{tabular}

Sumber : Dinas Peternakan Perikanan dan Kelautan Kabupaten Tasikmalaya, 2008

Tabel 2 . Produksi pembesaran air tawar di Kabupaten Tasikmalaya Tahun 2008.

\begin{tabular}{cccc}
\hline No. & Komoditi & $\begin{array}{c}\text { Produksi } \\
(\text { ekor })\end{array}$ & $\begin{array}{c}\text { Persentase } \\
(\%)\end{array}$ \\
\hline 1 & Mas & 3,656 & 19.91 \\
2 & Nila & 3,955 & 21.53 \\
$\mathbf{3}$ & Nilem & $\mathbf{6 , 9 1 0}$ & $\mathbf{3 7 . 6 2}$ \\
4 & Tawes & 1,163 & 6.33 \\
5 & Gurame & 364 & 1.98 \\
6 & Udang Galah & 23 & 0.12 \\
7 & Lele & 352 & 1.92 \\
8 & Lain-lain & 1,943 & 10.58 \\
\hline & Jumlah & $\mathbf{1 8 , 3 6 6}$ & $\mathbf{1 0 0 . 0 0}$
\end{tabular}

Sumber : Dinas Peternakan Perikanan dan Kelautan Kabupaten Tasikmalaya, 2008

Dilihat dari aspek pemanfaatan ikan gurame (7,83\%), ikan tawes $(7,55 \%)$, lahan perikanan, ikan nilem pun ikan lele (1,33\%) dan jenis ikan lainnya menempati persentase yang terbesar. (4,98\%). Data pemanfaatan areal Luas pemanfaatan areal budidaya untuk budidaya ikan berdasarkan komoditi dapat ikan nilem aadalah 111,61 Ha atau 37,22 dilihat pada Tabel 3. $\%$ dari total pemanfaatan, disusul dengan ikan mas $(24.06 \%)$, ikan nila $(17,03 \%)$, 
Tabel 3. Pemanfaatan areal budidaya berdasarkan komoditi di Kabupaten Tasikmalaya Tahun 2008

\begin{tabular}{cccc}
\hline No. & Komoditi & $\begin{array}{c}\text { Luas Areal } \\
(\mathbf{H a})\end{array}$ & $\begin{array}{c}\text { Persentase } \\
(\boldsymbol{\%})\end{array}$ \\
\hline 1 & Mas & 72.13 & 24.06 \\
2 & Nila & 51.06 & 17.03 \\
$\mathbf{3}$ & Nilem & $\mathbf{1 1 1 . 6 1}$ & $\mathbf{3 7 . 2 2}$ \\
4 & Tawes & 22.65 & 7.55 \\
5 & Gurame & 23.49 & 7.83 \\
6 & Lele & 3.99 & 1.33 \\
7 & Lain-lain & 14.93 & 4.98 \\
\hline & Jumlah & $\mathbf{2 9 9 , 8 6}$ & $\mathbf{1 0 0}$
\end{tabular}

Sumber : Dinas Peternakan Perikanan dan Kelautan Kabupaten Tasikmalaya, 2008

\section{Pembenihan Ikan Nilem di BPBI}

\section{Singaparna}

Wilayah Kabupaten Tasikmalaya memiliki 4 unit Balai Benih Ikan Air Tawar terdiri atas Balai Benih Ikan Rancapaku yang merupakan milik Pemda Kabupaten dan Balai Pengembangan Benih Ikan Unit Singaparna (Ceumceum), Balai Pengembangan Benih Ikan Unit Singaparna (Mongor), serta Balai Pengembangan Benih Ikan Unit Singaparna (Kokol) yang merupakan milik Pemprov Jawa Barat. Dari keempat Balai ini yang mengembangkan Ikan Nilem dalam kegiatan produksinya hanya di BPBI Singaparna Unit Ceumceum. Adapun kondisi pembenihan ikan nilem di BPBI Unit Singaparna dan pembudidaya dapat diuraikan sebagai berikut : Strain ikan nilem berwarna cokelat kehijauan pada punggungnya dan terang di bagian perut; Induk Ikan Nilem Umur 12 bulan (jantan dan betina), Berat induk 200 gram (betina) dan 150 gram (jantan), Panjang induk panjang total $21 \mathrm{~cm}$; panjang standar $17 \mathrm{~cm}$. Wadah Budidaya; Kontruksi wadah Kolam tembok; Kolam pemijahan 2 unit @ $50 \mathrm{~m}^{2}$; Kolam induk
2 unit @60 m² ; Kolam pendederan 6 unit @ $1.000 \mathrm{~m}^{2}$, Sumber air Irigasi (Cikunten), Kualitas air ;suhu $20-24{ }^{0} \mathrm{C}$; $\mathrm{pH}$ 6,5; oksigen terlarut $6 \mathrm{ppm}$, waktu Pemijahan sepanjang tahun, frekuensi pemijahan per tahun 6 kali. Jumlah stok induk $200 \mathrm{~kg} ; 100 \mathrm{~kg}$ betina dan $100 \mathrm{~kg}$ jantan. Sistem pemijahan secara semi intensif, dengan perbandingan induk $1: 3$, Fekunditas telur : $80.000-150.000$ butir telur/kg induk. Jumlah larva yang dihasilkan 1.200.000 ekor larva. Lama pemeliharaan pendederan 40 hari Survival rate $60 \%$. Jumlah benih yang dipanen (ukuran $1-3 \mathrm{~cm}$ ) 720.000 ekor.

\section{Pembenihan Ikan Nilem di Pembudidaya}

Pengamatan kondisi dan teknologi pembenihan ikan nilem di pembudidaya dilakukan pada tiga lokasi yaitu Kecamatan Padakembang, Sukaratu dan Sukarame. Adapun kondisi pembenihan ikan nilem dapat diuraikan sebagai berikut : Ikan nilem memiliki 3 strain yaitu ikan nilem merah, ikan nilem berwarna cokelat kehijauan pada punggungnya dan terang di bagian perut, ikan nilem were 
(berwarna putih keabuan seperti bandeng); Induk ikan nilem Umur; jantan 6 - 8 bulan, betina 10 - 12 bulan, berat induk 100 gram (betina) dan $80-100$ gram (jantan) Panjang induk panjang total betina $18-20 \mathrm{~cm}$; jantan $15 \mathrm{~cm}$, Kontruksi wadah kolam semi permanen. Sumber air : Irigasi (Cikunir), kualitas air suhu $24-26{ }^{0} \mathrm{C}$, pH 6,5, oksigen terlarut 6 ppm, waktu Pemijahan sepanjang tahun. Frekuensi pemijahan : sekitar 50 kali per tahun. Pemijahan secara semi intensif dengan menggunakan sistem gonggo (dasar kolam pasir), dengan perbandingan induk $1: 2$ atau $2: 3$, jumlah induk yang dipijahkan per siklus $30-40$ pasang induk. Jumlah larva yang dihasilkan per 30 pasang induk 100.000 ekor, Lama pemeliharaan pendederan $40-60$ hari, Benih yang dipanen Bebeas (pemeliharaan 15 hari), Aruy ( pemeliharaan 35 hari) ukuran $1-3 \mathrm{~cm}$, harganya $\mathrm{Rp}$ $17.000,00 / \mathrm{kg}$, Huripan (pemeliharaan 60 hari) ukuran $4-5 \mathrm{~cm}$, harga $\mathrm{Rp}$ $17.000,00 / \mathrm{kg}$, Koral (pemeliharaan 90 hari) ukuran $5-8 \mathrm{~cm}$, harga Rp 15.000 $16.000 / \mathrm{kg}$

Berdasarkan data di atas, perbedaan yang nyata terlihat pada pembenihan Ikan Nilem di Balai Benih dan pembudidaya adalah kualitas induk yang digunakan. Balai benih menerapkan seleksi induk (umur, berat, jenis) secara ideal sehingga fekunditas dan jumlah benih yang dihasilkan lebih tinggi dibandingkan hasil pembenihan di tingkat pembudidaya. Namun dari segi sistem pemijahan tidak terlihat beda nyata yang mengindikasikan dari segi teknologi, budidaya Ikan Nilem di Kabupaten ini sudah mantap. Lebih lanjut, berdasarkan hasil penelitian Djadjasewaka, 2006, pada pembenihan secara intensif (sistem induced breeding), tingkat kelangsungan hidup pada pembenihan Ikan Nilem dapat mencapai $80-90 \%$, sehingga dengan demikian masih dari segi produksi dan teknologi, pembenihan Ikan Nilem masih dapat dikembangkan.

\section{Strategi Konservasi Budidaya Ikan Nilem}

Peraturan Pemerintah RI Nomor 60 Tahun 2007 menegaskan bahwa konservasi sumberdaya ikan adalah upaya perlindungan, pelestarian dan pemanfaatan sumberdaya ikan, termasuk ekosistem, jenis dan genetik untuk menjamin keberadaan, ketersediaan dan kesinambungannya dengan tetap memelihara dan meningkatkan kualitas nilai dan keanekaragaman sumber daya ikan. Konservasi sumberdaya ikan ini meliputi konservasi ekosistem, konservasi jenis ikan dan konservasi genetik ikan.

Konservasi ikan dilakukan dengan tujuan ; a) melindungi jenis ikan yang terancam punah; b) mempertahankan keanekaragaman jenis ikan ; c) memelihara keseimbangan dan kemantapan ekosistem; dan d) memanfaatkan sumberdaya ikan secara berkelanjutan. Kegiatan konservasi ini berfungsi untuk memperbaiki sumberdaya perikanan dan menentukan cara penggunaannya agar menguntungkan secara terus menerus (lestari).

Mengacu pada Pedoman Pengelolaan Plasma Nutfah (2002), bentuk usaha dari strategi konservasi secara umum terdiri dari konservasi insitu dan konservasi ex-situ. Konservasi insitu bersifat pasif, karena dapat terlaksana dengan hanya mengamankan tempat 
tumbuh alamiah sesuatu jenis. Dengan demikian jenis-jenis tersebut diberi kesempatan berkembang dan bertahan dalam keadaan lingkungan alam dan habitatnya yang asli, tanpa campur tangan manusia. Konservasi in-situ, dilakukan dengan cara rasionalisasi penangkapan dan restorasi daerah reservat. Selanjutnya disebutkan bahwa cara kedua (ex-situ) dilakukan dengan lebih aktif, yaitu memindahkan sesuatu jenis ke suatu lingkungan atau tempat pemeliharaan baru. Konservasi ini merupakan komponen konservasi keanekaragaman hayati diluar habitat alaminya.

Berdasarkan hasil observasi lapangan, kegiatan konservasi yang dilakukan di Kabupaten Tasikmalaya adalah konservasi ex-situ, yang mencakup pemeliharaan populasi dalam bentuk wadah berupa kolam dan bak. Disamping itu, intensifnya kegiatan budidaya ikan nilem, baik yang dilakukan oleh Balai Benih maupun pembudidaya turut mendukung kemantapan populasi ikan nilem di wilayah ini. Sedangkan konservasi in-situ yang bersifat pasif hanya terbatas pada kegiatan restocking pada perairan umum. Kegiatan restocking yang dilakukan oleh sebagian pembudidaya di Kabupaten Tasikmalaya khususnya di Kecamatan Singaparna dengan cara menebar sebagian hasil pembenihannya untuk ditebar di perairan umum seperti situ dan sungai yang merupakan habitat alaminya namun demikian masih belum dapat meningkatkan populasinya diduga lingkungan perairannya yang sudah mengalami kerusakan akibat faktor alami maupun akibat andropogenik.
Untuk menjamin populasi ikan nilem di masa yang akan datang, maka diperlukan langkah-langkah dan strategi konservasi aplikatif yang dapat diterapkan oleh pembudidaya. Salah satu langkah yang dapat diterapkan adalah dengan terus mengembangkan kegiatan budidaya ikan (pembenihan, pendederan dan pembesaran), perlindungan jenis ikan di habitat alaminya (perairan umum), pelestarian jenis ikan nilem dengan melakukan restocking dan inventarisasi populasi ikan nilem terutama populasinya di perairan umum.

Keterlibatan masyarakat (Fisheries Based Community ) untuk pengembangan kegiatan budidaya ikan sangat diperlukan. Selain mengembangkan kegiatan budidaya ikan untuk peningkatan produksi juga perlunya menjaga kelestarian sumberdaya ikan melalui kegiatan restocking di perairan umum, restorasi daerah reservart dan kegiatan penangkapan ikan yang tidak merusak. Oleh karena itu kegiatan penyuluhan/pembinaan kepada masyarakat harus terus digalakkan untuk meningkatkan kesadaran masyarakat akan arti pentingnya konservasi sumberdaya ikan.

\section{KESIMPULAN DAN SARAN}

\section{Kesimpulan}

Berdasarkan hasil pengamatan dan observasi lapangan, beberapa hal yang dapat disimpulkan adalah :

1. Kabupaten Tasikmalaya memiliki potensi yang cukup besar dalam pengembangan budidaya perikanan air tawar khususnya dalam 
pengembangan komodias ikan nilem sebagai upaya peningkatan produksi dan konservasi sumber daya ikan.

2. Present status komoditas Ikan Nilem di Kabupaten Tasikmalaya :

- Areal budidaya Ikan Nilem seluas 111,61 Ha atau 37,22 \% dari total pemanfaatan areal cabang usaha pembenihan air tawar di Kabupaten Tasikmalaya;

- Persentase nilai produksi ikan nilem pada tahun 2008 sebesar $42,13 \%$ dari total produksi pembenihan ikan air tawar atau sejumlah 679.119.578 ekor;

- Persentase nilai produksi Ikan Nilem pada tahun 2008 sebesar $37,62 \%$ dari total produksi pembesaran ikan air tawar atau sejumlah 6.910 ton.

3. Teknologi budidaya khususnya pembenihan ikan nilem sudah berkembang baik dan diaplikasikan oleh pembudidaya. Pembenihan dilakukan sudah berada pada taraf semi intensif, pada kolam semi permanen dengan menerapkan seleksi induk sedangkan dalam kegiatan pendederan dilakukan secara polikultur pada kolam tanah.

4. Kegiatan konservasi yang dilakukan adalah konservasi ex-situ, yang mencakup pemeliharaan populasi dalam bentuk wadah berupa kolam dan bak. Dan konservasi in-situ melalui kegiatan restocking di perairan umum.

5. Keterlibatan masyarakat (Fisheries Based Community ) untuk pengembangan kegiatan budidaya ikan sangat diperlukan. dan kegiatan penyuluhan/pembinaan kepada masyarakat harus terus digalakan untuk meningkatkan kesadaran masyarakat akan arti pentingnya konservasi sumberdaya ikan.

\section{Saran}

Untuk menjamin populasi Ikan Nilem di masa yang akan datang, diperlukan langkah-langkah dan strategi konservasi aplikatif yang dapat diterapkan oleh pembudidaya. Langkah yang dapat diterapkan adalah dengan terus mengembangkan kegiatan budidaya ikan (pembenihan, pendederan dan pembesaran), perlindungan jenis ikan di habitat alaminya (perairan umum), pelestarian jenis ikan nilem dengan melakukan restocking dan inventarisasi populasi ikan nilem terutama populasinya di perairan umum.

\section{DAFTAR PUSTAKA}

Dinas Peternakan Perikanan dan Kelautan Kabupaten Tasikmalaya. 2008. Data Produksi Perikanan Budidaya Kabupaten Tasikmalaya. Provinsi Jawa Barat. Bandung, Jawa Barat.

Hadie W, L. Pouyaud and Lies E.Hadie. 2000. Strategi Konservasi Melalui Pendekatan Analisi mt-DNA: Kasus Pada Ikan Lele (Clarias batracus) di Pulau Jawa. Prosiding Seminar Nasional Keanekaragaman Hayati Ikan. 
Hardjamulia A. 1979. Budidaya Komisi Nasional Plasma Nutfah. 2002. Perikanan, Budidaya Ikan Mas Pedoman Pengelolaan Plasma (Cyprinus carpio), Ikan Tawes Nutfah. Deptan. Badan Litbang (Puntius javannicus), Ikan Nilem Pertanian.

(Osteochilus hasselti). Sekolah

Ilmu Perikanan. SUPM Bogor. Peraturan Pemerintah Republik Indonesia Badan Pendidikan, Latihan dan Penyuluhan Pertanian. Nomor 60 tahun 2007 tentang Departemen Pertanian.

Djajasewaka H dan Reza S. 2006.

Peningkatan Produksi dan Kualitas Telur Melalui Perbaikan Pakan Induk Ikan Nilem (Osteochilus hasselti). Balai Riset Perikanan Budidaya. Bogor. 